\title{
Development of nature protection measures after emergency spills of oil products
}

\author{
Y. Zelen'ko \& L. Yaryshkina \\ Dniepropetrovsk National University of Railway Transport, Ukraine
}

\begin{abstract}
In order to eliminate the environmental aftermath of transport accidents with oil products the cycle of laboratory research and field tests on the study of factors affecting the processes of migration of oil products in different types of soils was conducted. Comparison of convergence of the data on migration of oil products obtained in the laboratory conditions and field tests with the results of mathematical simulation of filtration processes in the same conditions is performed.

In the process of development of recommendations on application of sorbents for cleaning up of soils from oil products a wide spectrum of industrial wastes and natural materials was investigated, and the optimization of cleaning processes is conducted.

The kinetics of cleaning up of soils from light oil products by means of thermoconvection is studied. The estimation of degree of renewal of the cleaned soils is executed by biological testing.
\end{abstract}

Keywords: oil products, migration, soils, elimination of the environmental aftermath, sorbents.

\section{Introduction}

The analysis of ecological situations taking place in the system "transportnature-man" testifies to intensifying of the environmental problems in the industry and strengthening of negative tendencies in many links of transport technologies from the viewpoint of their influence on nature [1,2]. These problems are conditioned by the rates of development of transport and features of its interaction with the objects of the biosphere. 
One of the major problems of technogenic safety is the environmental contamination during transport accidents. In particular it touches railway transport accidents when the emissions of toxic and explosion-and-fire hazard substances into the environment are large-scale enough.

The environmental aftermath of accidents which occur during transportation of dangerous freights are one of the most meaningful problems of transport ecology. During such accidents the volley emissions of great amounts of toxic materials, which are seriously dangerous for people and the environment, take place $[3,4]$.

The oil products are one of the most widespread freights transported by railways. Ukraine is a transit country and along with plenty of internal consumers the quantity of consignees of this type of products increases in the West, as a result the number of Russian trains grows in the direction Asia Europe. However the number of accidents with these types of freights has also a tendency to grow.

The research work is devoted to the system research of dominant factors affecting the processes of migration of oil products, namely the L grade diesel fuel and the A-95 grade benzine, in most widespread soils of Ukraine (sandy loams, sandy soils, shell rocks, sands) taking place during transport accidents. The kinetics of migration is described by the relevant empirical equations, which allow the prediction of the depth of penetration for the corresponding time intervals.

The influence of the following factors has been studied for the process of filtration of oil products through soils: temperature of surrounding and soil, dispersion, humidity, compactness and chemical composition of soils.

On the basis of data obtained the mathematical simulation for further prediction of behaviour of oil products in soils with non-broken structure was performed.

The obtained values of speed differ substantially for the different types of soils; in particular the cases of diesel fuel have a higher viscosity. The systematic increase of speed of migration with growth of temperature is caused, undoubtedly, by the decrease of viscosity of oil products, and at negative temperatures the adfreezing of particles of soil and the diminishing of its filtering ability related to it becomes an additional factor.

The results of laboratory experiments on the influence of humidity of soils on speed of migration of diesel fuel and benzine are obtained [5]. It is interesting that this factor for diesel fuel and benzine has a different effect on both coarse and fine disperse soils. The facts of the obviously expressed increase of the filtering ability of loams and sandy soils in relation to diesel fuel with growth of humidity look especially unexpected.

For development of the technology of elimination of the environmental aftermath of transport accidents with heavy oil products we chose filling up of residues of the uncollected products by sorbents or, to say more correctly, absorbers as one of the stages of the technological cycle. Thus an orientation on the use of wastes of metallurgical, construction, woodworking industries, thermal power stations or some natural materials as such absorbers is a central 
conception of the technology. We aimed not only to choose cheap, accessible absorbers but also take those with a minimum time/number of processes of their preparation. With the purpose of the possibility of recommendation for using one or another material we investigated the effects of basic physical factors (temperature, humidity, granulometric and chemical compositions).

The kinetics of absorption of diesel fuel and benzine by the indicated absorbers is determined. In the case of benzine the state of saturation takes place already in 1-1.5 hour, while for the diesel fuel this period extends to 5-6 hours. It should be noted that, as shown by us in separate experiments, the absorptive power depends also on fraction composition, or in other words, on the sizes of absorber particles.

The consideration of problems of utilization of the materials saturated with oil products come from the following reasons: if utilization of benzine can take place by a few methods (for example by skimming of light fractions), for the case of diesel fuel the variant of direct burning down looks most simple and rational. In order to solve the question on expedience of burning down of one or other absorbers saturated with the diesel fuel and the design of the proper equipment, their heating value and ash content were determined.

The direct development of elimination measures in two basic directions differing by the character of run of emission, spreading of oil products and, accordingly, by the features of approach to their conduction, was a next stage of performance of this work.

The attention was concentrated on:

- elimination of the environmental aftermath of accidents during transportation of heavy oil products;

- elimination of the environmental aftermath of accidents during transportation of light oil products.

The basic principle of elimination of spills of heavy oil products is the generally recognized scheme:

Localization of place of spill $\rightarrow$ Pumping-out of liquid phase of oil product $\rightarrow$ Filling up of accident scene by absorbers $\rightarrow$ Collecting of exhausted absorbers and cutting-off of oil-contaminated soil $\rightarrow$ Ordering of collected absorber and cut-off soil to utilization $\rightarrow$ Treatment of accident scene by enzymes and biopreparations-oil destructors for deep final cleaning up of soil.

Thus an orientation on the use of industrial wastes and some natural materials as sorbents-absorbers is a central conception of the technology.

The basic principle of elimination of spills of light oil products is as follows:

Blowing of light fractions by air warmed up to the optimum temperatures (convection) with the parallel regeneration of oil product (Fig. 1) $\rightarrow$ Pumping-in of enzymes and biopreparations-oil destructors for deep final cleaning up of soil.

The analysis of the work of departmental structures on elimination of the aftermath of railway transport accidents has demonstrated that for effective elimination the following approaches to these works are needed: 


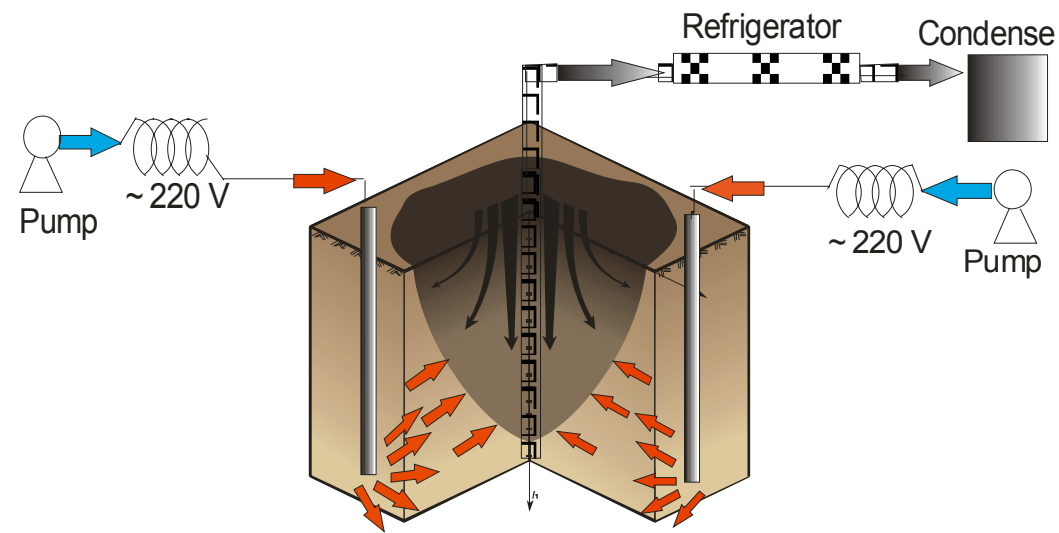

Figure 1: Principle of elimination of emergency spills of light oil products.

1. Development of new and processing of existing normative documents (including on legal aspects) of departmental and state structures on elimination of accidents, their mutual cooperation, control after the quality indices of removal of accident aftermaths.

2. Improvement of the system of operative checking of the conditions of transported ecologically dangerous freights including development of effective sensors of the state of freight and the rolling stock, the systems of information processing and transmission.

3. Organization of the special structure on control after transportation of dangerous freights with the use of existing structures (dispatcher's checking system).

4. Organization of the structure on decision making for the elimination of the aftermath of accidents (including the notification of the population of near-by settlements).

5. Development of effective technologies on neutralization of hazardous substances and elimination of their effect on the environment.

The results obtained have provided the basis of technology for elimination of the environmental aftermath of transport accidents with oil products. The offered technology has passed the successful tests at Prydniprovs'ka Railways and has become a part of the "Recommendations R003" of the Commission on Transport Policy, Ecology and Combined Transportation of the Organization for Railways Cooperation.

\section{References}

[1] Plakhotnik, V.N., Chemical aspects of transport influence upon the environment. Proc. 35 th IUPAC Gongress, eds. V.V Popov, A.Kh. Drabkina, L.A Yaryshkina. Istanbul, pp. 179-181, 1995. 
[2] Plachotnik, W., Sirakow, W., Jaryschkina, L. Ökologische aspekte von havarien der eisenbahnen der OSShD - mitgliedsländer Zeitschrift der OSShD. 6(6), pp. 7-9, 1997.

[3] Horn, M.E., Estimating soil permeability rates. Proc. Amer. Soc. Civil and Proc. Amer. Soc. Civil Engrs, vol. 97, №1, R2, pp. 263-274, 1971.

[4] Fagnoul, A.F., Influence of content of compaction water and of temporal evolution on permeability on sands. Ann. Trav. Publics Belg., № 4, pp. 307-320, 1969.

[5] Plakhotnyk, V., Zelen'ko, J. Environmental consequences of transport accidents with oil products in Ukraine: problem of pollution of grounds and underground water sources. Scientific Israel - Technological Advantages. vol.6, № 1-2, pp 197-200, 2004. 